\title{
Os filmes de Arthur Omar como "formas que pensam" a violência no Brasil dos anos 1980
}

\section{Rosane Kaminski}

Doutora. Universidade Federal do Paraná, Curitiba, PR, Brasil Rosanekaminski@gmail.com

\begin{abstract}
Resumo
Arthur Omar é um cineasta e artista visual atuante desde os anos 1970 até hoje. Nos anos 1970-80, caracterizou-se por fazer um cinema cuja inventividade de linguagem pode, sem muito esforço, ser discutida nos termos de uma violência poética. Em seus filmes, enfatizava uma multiplicidade de aspectos da realidade articulados de forma complexa e sem obviedade. Ao longo da década de 1980 realizou, entre outras obras, os filmes O Som ou tratado da harmonia (1984), O Inspetor (1987) e Ressurreição (1988), que serão aqui discutidos. Neles, além dos desdobramentos da poética violenta característica de suas primeiras obras, a violência enquanto fenômeno social também se torna assunto relevante. $O$ presente texto pretende discutir esses três filmes enquanto uma "teoria da violência" proposta por Arthur Omar em suas obras, e situá-los em meio aos debates estéticos e políticos do seu tempo de produção. 0 artigo resulta de estudos feitos nos últimos anos sobre os filmes de Omar, e também sobre as relações entre cinema e violência. O método utilizado articula a análise fílmica às discussões acadêmicas e culturais do contexto em que as obras de Omar foram produzidas.
\end{abstract}

\section{Palavras-chave}

Arthur Omar. Cinema brasileiro. Violência. Teoria dos cineastas.

\section{Introdução}

Arthur Omar é um cineasta e artista visual brasileiro atuante desde os anos 1970 até hoje. Em 1972, realizou o curta 0 Congo, e em 1974 o longa Triste trópico, filmes que se 
destacaram por uma inventividade de linguagem que pode, sem muito esforço, ser discutida nos termos de uma violência poética ${ }^{1}$.

Esses filmes se caracterizam pela oposição ao documentário-padrão ou, segundo Jean-Claude Bernardet (1985), ao modelo "sociológico" que era recorrente nos documentários brasileiros desde os anos 1960. Tal modelo consistia numa "[...] forma de registro das tradições populares, da arquitetura, das artes-plásticas, da música, etc." (BERNARDET, 1985, p. 7) com posicionamento didático. No início dos anos 1970, passou a ser questionado por "[...] documentários inquietos tanto com os problemas sociais como os da linguagem." (BERNARDET, 1985, p. 7-8). Os filmes de Arthur Omar se engajavam nessa posição questionadora. Neles, múltiplos aspectos da realidade são articulados de forma complexa e sem obviedade. Quando da exibição do recém-finalizado Triste Trópico no Museu de Arte Moderna do Rio de Janeiro em 1974, Bernardet (2009) comentou a "perturbação" causada por aquele "[...] filme de pesquisa radical, que questiona[va] a maneira de fazer cinema e a maneira de o cinema se relacionar com a realidade." (BERNARDET, 2009, p. $214)^{2}$.

Na década seguinte, Arthur Omar se aproximou do vídeo e de outras mídias artísticas, mas também produziu curtas e médias metragens em película, dentre os quais destacarei, neste texto, O Som ou tratado da harmonia (1984), O Inspetor (1987) e Ressurreição (1988).

Nesses três filmes, além dos desdobramentos de sua poética violenta, a violência em si amplifica-se como tema relevante. Se Triste Trópico já ironizava a violência associada ao messianismo como forma de crítica à nação ${ }^{3}$, agora viriam à tona a violência política, o crescimento da violência nos grandes centros urbanos, os assassinatos, a brutalidade da polícia em relação aos chamados "delinquentes", as chacinas, entre outras situações traumáticas na sociedade brasileira dos anos 1980. Pretendo, portanto, discutir esses três filmes enquanto uma teoria da violência formalizada por Arthur Omar em suas obras, e situá-lo em meio aos debates estéticos e políticos do seu tempo de produção.

0 texto está organizado em duas partes. Na primeira, os filmes de Omar são situados enquanto "formas que pensam", com auxílio das proposições de Phillipe Dubois (2004). Este

\footnotetext{
${ }^{1}$ Além desses dois filmes que se destacaram pela invenção, na década de 1970 Arthur Omar também realizou: Serafim Ponte Grande e Sumidades Carnavalescas, ambos de 1971; O anno de 1798 em 1975, Tesouro da Juventude em 1977 e Vocês em 1979. Em 1981, realizou Música Barroca Mineira.

2 Trata-se de um excerto de texto publicado originalmente em 1974 no jornal Opinião, sob pseudônimo.

3 Ismail Xavier (1997) explica que Triste Trópico “[...] encontra a tradição alegórica do cinema brasileiro moderno centrada na questão do messianismo [e no qual] a América tropical é ponto de acumulação da violência [...]” (XAVIER, 1997, p. 9). Nesse filme, a barbárie e o sincretismo da experiência religiosa no contexto brasileiro entrelaçam-se o tempo todo.
} 
autor discute o vídeo não como técnica ou linguagem, mas sim como forma pensante (DUBOIS, 2004, p. 28), caracterizada pelo “[...] senso constante do ensaio, da experimentação, da pesquisa, da inovação." (DUBOIS, 2004, p. 77). 0 objetivo, nessa parte, será refletir sobre a elaboração formal complexa e provocativa dos filmes de Omar, que emaranham formas artísticas diversas, que pensam por meio da forma fílmica, e não através dela.

Na segunda parte do texto, argumenta-se a possibilidade de aferir uma teoria da violência nesses filmes pensantes de Arthur Omar, como parte do debate crítico que se processava sobre o tema. É essa a principal proposição do artigo, que resulta de estudos feitos nos últimos anos, tanto sobre os filmes de Omar, quanto sobre as relações entre cinema e violência 4 .

\section{0 vídeo como forma que pensa e o cinema de Arthur Omar}

No âmbito audiovisual, a década de 1980 foi marcada, entre tantas outras coisas, por uma discussão sobre as especificidades e as articulações entre cinema e vídeo. Isso ocorreu, ao mesmo tempo, numa esfera teórica e numa esfera prática. Se nas décadas de 60 e 70 vários artistas plásticos fizeram vídeos “[...] porque o que desejavam fazer podia ser melhor expresso em vídeo [...]" (FRICKE, 2005, p. 604), nos anos 80 vários cineastas produziram filmes com características videográficas. 0 ponto de partida para essa afirmação é a definição de vídeo proposta por Philippe Dubois (2004) já desde aquela década, pois a ele não interessa uma suposta especificidade do vídeo enquanto meio, interessa observá-lo como um "[...] estado, modo de pensamento (das imagens em particular), forma que pensa." (DUBOIS, 2004, p. 110). Portanto, um filme feito em película também pode ser videográfico, pois esta característica depende antes da inventividade ou, como diz Dubois (2004), de um "senso constante do ensaio".

Hoje, com a distância de mais de três décadas, essa simultaneidade de produções práticas e teóricas ocorridas nos anos 1980 permite observar uma movimentação no campo do audiovisual que mesclava características documentais, ficcionais, metalinguísticas e artísticas na busca de novos meios de relacionar o audiovisual e a realidade social.

\footnotetext{
${ }^{4}$ Resultados dessas pesquisas podem ser conferidos em: Kaminski (2016a), Kaminski (2016b), Kaminski (2017) e Kaminski (2018).
} 
Essa movimentação também era visível na obra de alguns cineastas brasileiros nos anos 80, em especial nos filmes de Arthur Omar. Já disseram, sobre os seus primeiros curtas, que eram "cinema experimental" (CANONGIA, 1981, p. 14), ou então "filmes-ensaio" (BENTES, 2001, p. 85). Nesse sentido, a abordagem sobre o aspecto ensaístico e intercambiante nos filmes de Omar tem, aqui, o objetivo de refletir sobre a potência política implicada no experimentalismo estético do autor, nos termos de uma reflexão sobre a violência.

O debate acerca das relações entre o estético e o político é denso e possui longo lastro. Numa palestra proferida na década de 1930, Walter Benjamin já explanava sobre essa dimensão. Dizia ele que um romance, por exemplo, não é político simplesmente quando seu conteúdo divulga ideologias partidárias através de métodos narrativos convencionais, e sim quando participa da fabricação dos "meios de produção" artística, atritando as técnicas literárias do seu tempo (BENJAMIN, 1994, p. 131). 0 filósofo recomendava aos artistas que estivessem atentos às mudanças de percepção ocorridas na sociedade europeia daqueles anos, articuladas ao surgimento dos novos meios de comunicação (no início do século XX, a fragmentação típica da edição de textos e imagens publicados em jornais e revistas, das reportagens de rádio e da montagem cinematográfica). Naquele mesmo contexto europeu marcado pelas vanguardas artísticas, teria surgido a máxima de que "não há arte revolucionária sem forma revolucionária" (CAMPOS; PIGNATARI; CAMPOS, 1987, p. 158), atribuída a Maiakóvski pelos poetas concretos, que a difundiram no Brasil 5 .

Pode-se dizer que essa discussão atravessou o século XX e estende-se até os dias atuais. O filósofo Jacques Rancière (2005) continua defendendo a potência política dos experimentalismos das vanguardas artísticas, dentro do que ele considera um "regime estético" da partilha do sensível (a existência de um comum e dos recortes que nele definem lugares e partes respectivas, como a língua, e também os produtos culturais). Às vezes, esta relação entre arte e política é nostalgicamente posta num tempo passado, especialmente no começo do século $\mathrm{XX}$, quando a arte andou lado a lado com as utopias políticas de transformação social, ou então nos anos 60 no Brasil, quando, apesar de ser regido por um regime de direita, constatava-se a hegemonia da produção cultural de esquerda (SCHWARZ, 2001).

\footnotetext{
5 Em 1961, os poetas Augusto de Campos, Décio Pignatari e Haroldo de Campos inseriram a máxima ao Plano Piloto Para poesia Concreta como post-scriptum, seguida do nome do poeta russo. A versão original do Plano Piloto data de 1958. Ver: (CAMPOS; PIGNATARI; CAMPOS, 1958).
} 
A produção fílmica de Arthur Omar dos anos 80, tratada aqui, apresenta um aspecto bem mais irônico do que utópico no tensionamento da percepção e das interpretações sobre o mundo. É a partir desse enfoque que privilegia o âmbito político de um fazer artístico investigativo e coerente com os debates mais candentes do seu tempo, que seus filmes produzem uma teoria. Ou seja, os filmes podem ser avaliados dentro de um quadro mais amplo dos debates sobre cinema e arte que perpassam àquela década, se cotejados aos textos teóricos que debatem o estatuto do cinema e do vídeo ao longo das décadas de 70 e 80. Mas também podem ser avaliados dentro de um quadro cultural específico, em que se avaliava criticamente o fenômeno histórico da violência no Brasil. Vejamos.

\subsection{Som (1984)}

Desde o início da sua carreira, Arthur Omar fez uso do cinema, mas não se restringiu a ele. Ivana Bentes (2001, p. 60) diz que sua obra “[...] é um importante ponto de convergência e passagem entre os meios e suportes." Quando elaborou $O$ som ou tratado da harmonia (1984), curta-metragem de 16 minutos filmado em $35 \mathrm{~mm}$, o artista se propôs a produzir um documentário sobre a experiência sonora e suas implicações emocionais, políticas e identitárias. 0 filme apresenta uma linguagem complexa e, ao mesmo tempo, discute as violências do regime militar brasileiro. Inclui trechos dos depoimentos do exguerrilheiro Herbert Daniel sobre Carlos Lamarca, e também sobre os seus dilaceramentos identitários enquanto homossexual envolvido nas lutas contra a ditadura militar6.

No que concerne à linguagem do filme, observa-se que o cineasta manteve alguns elementos narrativos da estrutura do documentário padrão: (1) a presença de narradores (no início e no fim do curta), (2) os trechos de entrevistas e depoimentos (com o exguerrilheiro Herbert Daniel, com uma terapeuta e com uma bailarina), e (3) uma visão científica sobre o assunto som (dissecação do ouvido que chega ao cérebro para mostrar como funciona a audição; explicações sobre acordes harmônicos e dissonantes). Todavia, mesmo mantendo esses elementos, Omar o faz sem criar uma linearidade evidente e sem didatismos, pois preserva a ironia em relação à linguagem do documentário, característica

\footnotetext{
${ }^{6}$ Ex-capitão do Exército, Carlos Lamarca abandonara o quartel para comandar o grupo armado VPR (Vanguarda Popular Revolucionária) e lutar contra a ditadura militar. Herbert Eustáquio de Carvalho, conhecido como Herbert Daniel, foi jornalista e integrante da luta armada contra a ditadura militar no Brasil, tendo participado, entre outras formações guerrilheiras, do grupo de Carlos Lamarca. Exilou-se do país em 1974. Depois de anistiado, voltou ao Brasil em 1981. Faleceu em 1992. Concedeu depoimento a Arthur Omar para a realização do filme $O$ Som ou tratado da harmonia (1984). Maiores informações em GREEN, 2018.
} 
presente desde os seus primeiros filmes. Em sua dissertação de mestrado, Ramos (1995) demarcou algumas fases na produção fílmica de Arthur Omar, a partir das características das obras desse cineasta7. Segundo ela, $O$ som ou tratado da harmonia situa-se num momento em que os filmes de Omar apresentavam uma relação positiva com o tema tratado, e o assunto som pôde ser desenvolvido, ainda que não de modo convencional.

Ramos (1995) debruçou-se minuciosamente sobre esse filme, e identificou nele uma estrutura em dois movimentos: na primeira parte, ou "primeiro movimento", o "som é o assunto". Depois há uma passagem composta de três sequências, e finalmente, na segunda parte ou "segundo movimento", o "som é a referência" para a abordagem de outros assuntos. (RAMOS, 1995, p. 58-87).

A discussão sobre som acontece sobretudo por meio da polifonia, sobrepondo ruídos, músicas, narrações, depoimentos e efeitos estranhos ${ }^{8}$. A banda sonora do filme não atua como complemento visual, mas como contraponto, contraste, friç̧ão. 0 filme também flerta com outras formas de arte, por meio das sequências quase autônomas que operam como instalações artísticas ou situações performáticas dentro de sua estrutura.

Como um todo, a montagem fragmentária e bastante complexa amontoa imagens, sons e falas que se atritam diante do espectador, exigindo uma posição crítica e participativa na produção de sentidos. Assim, minha opção por eleger o personagem Herbert Daniel como eixo condutor das discussões sobre violência no filme permitirá, na segunda parte deste texto, argumentar em favor de uma escolha do cineasta de dar visibilidade a esse tema, não de forma óbvia, mas como uma camada espessa que perpassa o curta-metragem, ganhando mais intensidade política nas sequências finais.

Retomarei alguns desses pontos no próximo tópico. Por ora, importa ressaltar que esse aspecto fragmentário do filme é indicativo da atitude pensante de Omar em relação à linguagem fílmica, seus limites, suas tangências com outras expressões artísticas. Ele faz uso da linguagem como criação, e não apenas como veículo de ideias prontas. Seu filme situa-se naquele sentido de "forma que pensa", proposto por Dubois (2004, p. 28) para refletir sobre a produção audiovisual que fervilhava nos anos 1980.

\footnotetext{
7 Ramos (1995, p. 23-24) observa três momentos na obra fílmica de Arthur Omar entre 1972 e 1984. Um primeiro momento de "negação do documentário padrão" (filmes de 1972 até 1975); seguida de um momento de composição fílmica mais abstrata, sem referência a um tema (filmes de 1977 a 1979), e de um terceiro momento marcado pela busca de produção de sentido numa relação positiva com o tema proposto (filmes de 1981 e 1984).

${ }^{8}$ Ricardo Miranda é o responsável pela montagem de 0 Som ou tratado da harmonia (1984).
} 


\subsection{Inspetor só terá sentido se funcionar como Ressurreição}

Na mesma década de $O$ som ou tratado da harmonia (1984), Arthur Omar fez os seus últimos filmes em 35mm, que são O Inspetor (1987) e Ressurreição (1988), ambos versando sobre a violência urbana. $O$ filme $O$ Inspetor (1987) tem 11 minutos, aborda os métodos, a psicologia e a filosofia do famoso detetive de polícia Jamil Warwar, que lutava contra o crime com métodos pitorescos. Warwar tornou-se conhecido no final dos anos 70, quando desvendou um caso de homicídio no Rio de Janeiro, cujo autor era filho de um industrial carioca e envolvido com o tráfico de cocaína ${ }^{9}$. Ao invés da prisão do assassino, o resultado foi o silenciamento do detetive e a sua transferência para uma cidadezinha do interior. 0 filme, feito dez anos depois desse caso, ironiza o trabalho da polícia e elege Warwar como espécie de herói quixotesco. Um policial que acredita na possibilidade de acabar com o crime. 0 curta traz depoimentos do próprio detetive, mas enfatiza os seus disfarces e a sua atuação como ator de fotonovelas, apontando para os limites tênues entre realidade e ficção. Há presença da voz de um narrador, que é o próprio Arthur Omar recitando frases aparentemente desconectadas, mas que sempre provocam algum tipo de tensão com o que está sendo mostrado nas imagens, ou o que está sendo dito pelos depoentes. 0 tom, no geral, é bastante debochado. A montagem fragmentária segue o estilo dos filmes anteriores de Omar ${ }^{10}$.

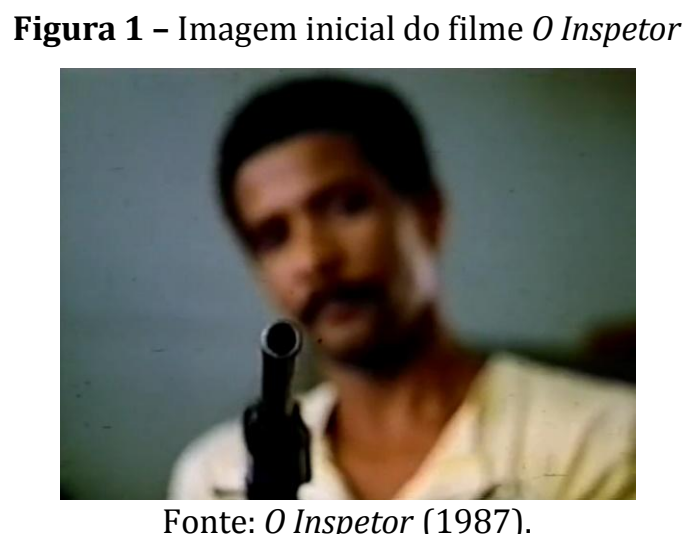

\footnotetext{
9 Trata-se do caso do assassinato de Cláudia Lessin Rodrigues, em julho de 1977, amplamente divulgado na imprensa e cujo inquérito se estendeu por vários anos. Mais detalhes em Kaminski (2016a, p. 252-254).

${ }_{10}$ Aida Marques fez a montagem de O Inspetor e de Ressurreição.
} 
Figura 2 - Close na arma com selo do Exército Brasileiro, sequência final do filme

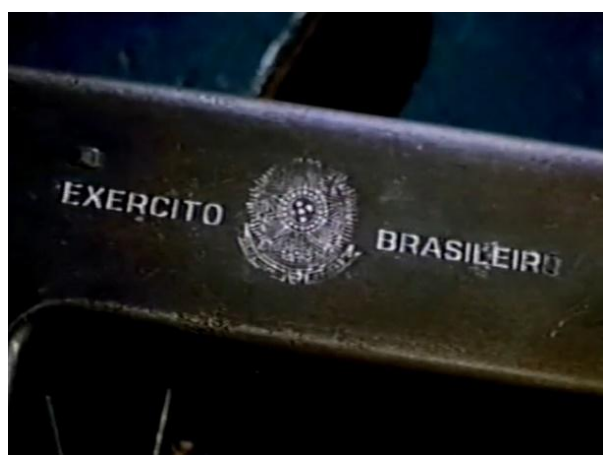

Fonte: O Inspetor (1987).

Figura 3 - Imagem de arma na sequência final do filme

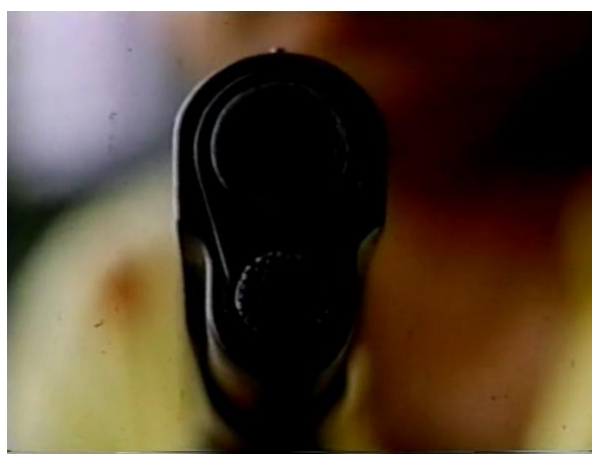

Fonte: O Inspetor (1987).

Figura 4 - Imagem de arma nos segundos finais do filme

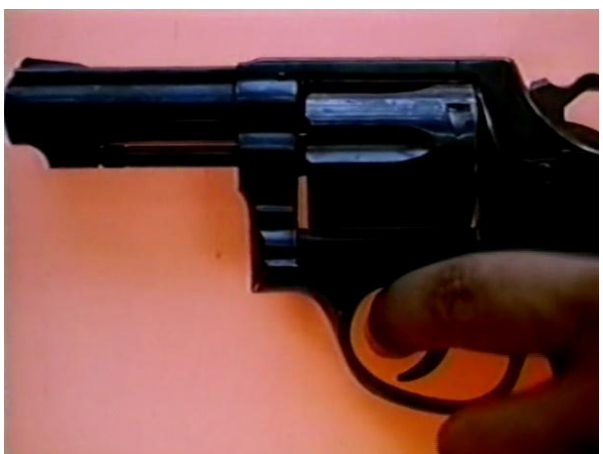

Fonte: O Inspetor (1987).

Um ponto a ressaltar, aqui, é que o filme inicia e termina com a imagem de armas de fogo sendo empunhadas. A primeira imagem (Figura 1), ainda antes do título do filme, é de um homem de pele escura, um pouco desfocado, que aponta uma arma diretamente ao espectador. A ponta do cano da arma é o elemento mais nítido na cena. 
Ao som de um hino (ou marcha militar orquestrada), as imagens finais são de armas vistas de vários ângulos, em planos curtos, enquanto a voz de Omar diz: "Este filme só terá sentido para ele se funcionar como ressurreição." (O INSPETOR, 1987, doc. não paginado). Nesse momento é mostrado o Selo Nacional e a inscrição do Exército Brasileiro na arma, que aparece em close (Figura 2). Logo, o cano da arma novamente apontado para o espectador (Figura 3), como ocorrera no início do filme, mas em um close bastante enfático, com a pessoa ao fundo ainda mais desfocada. Por último, uma mão aparece em cena e empunha a arma num plano de perfil (Figura 4). A voz diz: "Até breve, inspetor!" (O INSPETOR, 1987, doc. não paginado). A marcha cessa, entra uma música cinematográfica cuja função é criar tensão, a câmera mergulha numa página de fotonovela na qual Warwar beija a mocinha e o filme encerra com um grito de horror e uma percussão.

Se a primeira imagem do filme (Figura 1) é ambígua, pois não há menção à identidade do homem que aponta uma arma para a câmera (afinal, é um policial à paisana ou um "bandido"?), nos segundos finais do filme (Figuras 2 a 4) não há dúvida alguma de que a arma de fogo que nos é mostrada em vários ângulos pertence ao Exército (independente de quem a empunha). As frases finais, contendo as palavras "ressurreição" e o "até breve", somadas às imagens de armas, criam uma continuidade com o filme seguinte.

Nos dois filmes já comentados, observa-se que o cineasta manteve alguns dos elementos narrativos do documentário padrão, como a presença de narradores e os trechos de entrevistas e depoimentos. Já em Ressurreição (1988), ele não faz uso de legendas ou narrações verbais. Apenas a montagem feita com fotografias e as duas músicas religiosas.

0 curta Ressurreição (1988) tem 6 minutos e é composto com fotografias do Instituto Médico Legal e de arquivos de jornais populares especializados em assassinatos violentos, todos ocorridos nas periferias do Rio de Janeiro. Há clara remissão às ações dos esquadrões da morte, assunto que retomarei na segunda parte do texto. As fotos são justapostas a dois cantos religiosos entoados por Carmem Costa e Agnaldo Timóteo, que organizam o filme em dois momentos. Os aplausos e assovios aos cantores, que ouvimos no início e no final do filme, provocam estranhamento e náusea quando associados às imagens do horror. Se ainda há deboche, ele é suplantado pela morbidez e um certo mau gosto.

Enfim, algumas questões teóricas são tensionadas a partir desse conjunto de filmes de Arthur Omar, concernentes à capacidade reflexiva das próprias linguagens e formas artísticas: É possível pensar por meios não-verbais ou através de uma narrativa não- 
teleológica? E como essa proposta se articula às questões mais candentes nos debates culturais e políticos do seu tempo de produção?

Quanto à capacidade reflexiva de meios como o cinema ou o vídeo, os teóricos Jacques Aumont (1996) e Phillipe Dubois (2004) defendem a noção de "ensaio audiovisual" que inclui o "filme ensaio", os "ensaios de vídeo" e também o cinema como "forma de pensamento", já mencionado. Jacques Aumont (1996) diz que o cinema nos faz pensar sobre ideias e sobre sentimentos através de um discurso de imagens e sons que pode ser tão denso quanto o discurso das palavras. Para ele, foi a partir do filme $O$ homem da câmera, de Vertov, que o cinema se tornou uma nova forma de escritura, isto é, de interpretação do mundo. Na opinião de Arlindo Machado (2003, p. 10), somente com Jean-Luc Godard que o "cinema ensaio" chegaria à sua expressão máxima, por meio de filmes produzidos nos anos 60 e que não são ficção, pois não possuem enredo ou força dramática, e que não são, ao mesmo tempo, documentários no sentido mais tradicional, pois fazem uso de atores e situações encenadas. São reflexões sobre um tema. O próprio Godard (CAHIERS DU CINÉMA, 1962) afirmava-se enquanto "ensaísta" dizendo que ao invés de escrever ensaios, ele os filmava.

Segundo Adorno (198411 apud MACHADO, 2004, p. 17), o que define um ensaio (na forma escrita) são atributos literários como a subjetividade do enfoque (explicitação do sujeito que fala), a eloquência da linguagem (ou preocupação com a expressividade do texto), e a liberdade de pensamento (concepção de escritura como criação, em vez de simples comunicação de ideias). 0 ensaio distingue-se do mero relato científico ou da comunicação acadêmica nos quais a linguagem é antes de tudo instrumental. No ensaio, destaca-se o manejo da linguagem escrita. Nesse sentido, Arlindo Machado (2004) destaca, nas últimas décadas, o "[...] surgimento de uma discussão sobre a possibilidade de ensaios não escritos, ensaios em forma de enunciados audiovisuais." (MACHADO, 2004, p. 17). Penso que aí pode-se localizar a intervenção fílmica de Arthur Omar. Seus filmes e também os seus vídeos consistem em enunciados audiovisuais que não tem um enredo ou narrativa ficcional (no sentido mais tradicional da ideia de narrativa no cinema), mas apresentam enunciados reflexivos sobre o próprio universo da linguagem cinematográfica, e também sobre questões estéticas, políticas, filosóficas, afetivas e, como será discutido a seguir, sobre a violência.

${ }^{11}$ ADORNO, Theodor. Notes sur la littérature. Paris: Flammarion, 1984. 


\section{Uma teoria da violência nos filmes de Arthur Omar}

Os anos 80 no Brasil foram marcados pela ampliação da visibilidade e dos debates sobre violência. Ao mesmo tempo em que o fenômeno da violência social não era mais abafado pela censura, em tempos de abertura política, o tema passou a ser pesquisado por antropólogos e sociólogos brasileiros que buscavam desmistificar a ideia de "brasileiro cordial", e denunciar a prática da violência como uma ferramenta de manutenção das desigualdades e da dominação política.

Enquanto se evidenciava o crescimento dos índices de violência nas grandes cidades, comumente atribuídas às periferias e ao crime organizado, autores como Sergio Adorno (2002), Paulo Sergio Pinheiro (1979), Marilena Chauí (1980), Alba Zaluar (1999) e Gilberto Velho (2002) denunciavam a violência da polícia e dos esquadrões da morte, discutindo a violência como um traço estrutural da sociedade brasileira, favorável às elites, e cujas principais vítimas são os homens negros e pobres das periferias.

Artistas também participaram ativamente dos debates críticos sobre a violência. Nas artes visuais, já nos anos 60 apareceram trabalhos que, além de problematizar a corporeidade da obra de arte em si, fizeram uma crítica intensa da violência policial. São os casos das obras de Helio Oiticica de 1966 intituladas B33 Bólide-caixa nọ18 - Homenagem a Cara de Cavalo e o B44 Bólide-caixa no21 - caixa poema 3, que homenageiam como heróis dois bandidos executados impetuosamente pela polícia ${ }^{12}$. Anos mais tarde, um pouco posteriores aos filmes de Arthur Omar, mas também emblemáticos dessa discussão, são os trabalhos Atentado ao Poder, de 1992 e Candelária, de 1993, ambos de Rosangela Rennó, e 111 de Nuno Ramos, exposto pela primeira vez em 1992. Todos estes trabalhos são instalações que denunciam e questionam a violência da polícia em casos de chacinas (como a da Candelária no Rio e a do presídio do Carandiru, em São Paulo).

Também no cinema brasileiro já existia uma tradição em discutir a violência ao menos desde os anos 60. Essa tradição não se resume a filmes que representam a violência enquanto fenômeno social, mas inclui filmes que podem ser nomeados violentos na linguagem, nos modos de narrar. É o que caracteriza, por exemplo, os filmes do Cinema

\footnotetext{
12 A obra B33 Bólide-caixa nº18 - Homenagem a Cara de Cavalo, realizada em 1966, inclui quatro cópias da fotografia do cadáver de Manoel Moreira, jovem traficante conhecido como Cara de Cavalo, que era amigo pessoal de Hélio Oiticica, e que foi morto em 1964 como vingança pelo assassinato de Milton Le Cocq de Oliveira, policial influente que pertencia à elite de um grupo de extermínio. A referida fotografia havia estampado capas de vários jornais. 0 B44 Bólide-caixa no21 - caixa poema 3, também de 1966, é menos conhecido, e inclui uma fotografia do cadáver de Alcir Figueira da Silva que, após um assalto a banco, se suicidou às margens do rio Timbó para não ser preso, acuado pela polícia.
} 
Novo e do Cinema Marginal que, resultantes das buscas dos artistas para lidar com "o descompasso entre expectativas nacionais e realidade" (XAVIER, 2012, p. 29), desconstruíram a narrativa clássica, abriram mão da teleologia e mergulharam num acirrado debate sobre a linguagem cinematográfica. 0 mesmo tipo de postura é visível também nos filmes de Arthur Omar.

No rastro desses experimentos estéticos, João Luiz Vieira (1994) detectou na produção de curtas brasileiros na virada dos anos 80-90, uma tendência à invenção de estratégias reflexivas tanto no assunto narrado quanto no próprio processo de narração. Ele diz que esses traços estavam em sintonia com um cinema internacional contemporâneo, mas também tinham como referência o cinema mais experimental feito no Brasil dos anos 1960-70. A "violência estética" dos curtas experimentais do final dos anos 1980 e início dos 90, portanto, remonta ao cinema brasileiro moderno dos anos 1960-70 (VIEIRA, 1994, p. 716).

Numa pesquisa recente sobre a produção de curtas desse período, foram levantados cerca de 50 filmes feitos no Brasil abordando violência (KAMINSKI, 2017). Alguns casos, com linguagem mais convencional, outros, com maior grau de invenção. Nesse conjunto de filmes, a representação crítica da violência aparece entrecruzada com outros temas como classe, crime, política, corrupção, gênero e ambiente urbano. No grupo dos filmes mais inventivos, situam-se justamente os curtas de Arthur Omar aqui discutidos, violentos no âmbito estético e também no semântico.

Com o intuito de argumentar que os três filmes selecionados acabam por constituir uma teoria do cineasta sobre a questão da violência, serão elencados, a seguir, alguns pontos para discussão em cada filme.

\subsection{0 ex-guerrilheiro}

No filme O Som, ou tratado da harmonia (1984) destaca-se, como antes dito, a presença intensa dos depoimentos de Herbert Daniel, ex-guerrilheiro e exilado político. Sobre essa proeminência, Omar (1994) declarou que foi resultado do processo de trabalho:

Eu fui pegando depoimentos que falavam de sexualidade, política, sexo e som. Tudo isso pode estar um pouco sintetizado no depoimento do Hebert. Mas eu não queria fazer um filme sobre ele, ou com ele, porque seria 
privilegiar uma pessoa que fala desses assuntos explicitamente. E eu não acho que quem fale de política, sexo, etc., explicitamente, esteja mais próximo desses assuntos do que quem não fala explicitamente. (OMAR, $1994, \mathrm{~s} / \mathrm{p}$.

O testemunho de Herbert foi fracionado e remontado na junção com outros elementos, outros sons, imagens diversas, situações performáticas. As questões terapêuticas, as narrações de sonhos, os cenários que evocam instalações artísticas, compõe um mosaico fílmico que, a cada movimento, transforma-se como num caleidoscópio. Assim, apesar de não haver, ao longo de todo o filme, nenhuma imagem do ex-guerrilheiro prestando seu depoimento, há três momentos em que ouvimos suas memórias.

A primeira audição da voz de Herbert Daniel se dá nos minutos iniciais do curta (2' e $\left.15^{\prime \prime}\right)$, num trecho em que o assunto central é a íntima articulação entre som e identidade. Por cerca de 20 segundos, Herbert descreve o timbre da voz de Lamarca, “[...] voz anasalada que ficava metálica quando ele estava nervoso." (O SOM ou tratado da harmonia, 1984). Suas falas surgem após a visão cirúrgica de uma orelha sendo cortada para o estudo científico do órgão auditivo, da pele que vai descolando durante o corte, até a imagem ser substituída por um close em um cérebro, momento em que começa a voz. 0 tom de depoimento, que enfatiza a dimensão emocional do ser humano, contrasta com o caráter de dissecação das imagens que vimos nessa introdução de um filme sobre tema acústico (o som). No entanto, o depoimento em si também nos chega pelo órgão auditivo (não vemos o depoente, apenas o ouvimos), e por mais que ele esteja falando de timbre (qualidade do som), a mera expressão do nome e dos estados emocionais de Lamarca, um dos mais proeminentes líderes guerrilheiros da luta armada contra a ditadura militar, confere o tom político e memorialístico à sua fala.

Figura 5 - Cena de dissecação de um ouvido

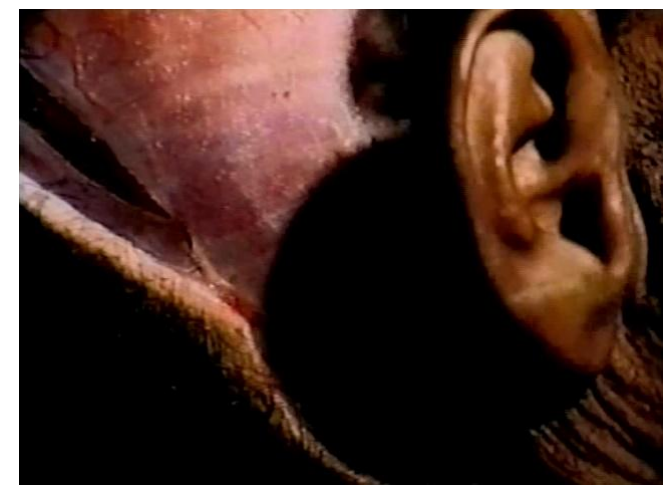

Fonte: O som, ou tratado da harmonia (1984). 
Figura 6 - Cena da aparição de um cérebro, enquanto ouve-se um trecho do depoimento de Herbert Daniel

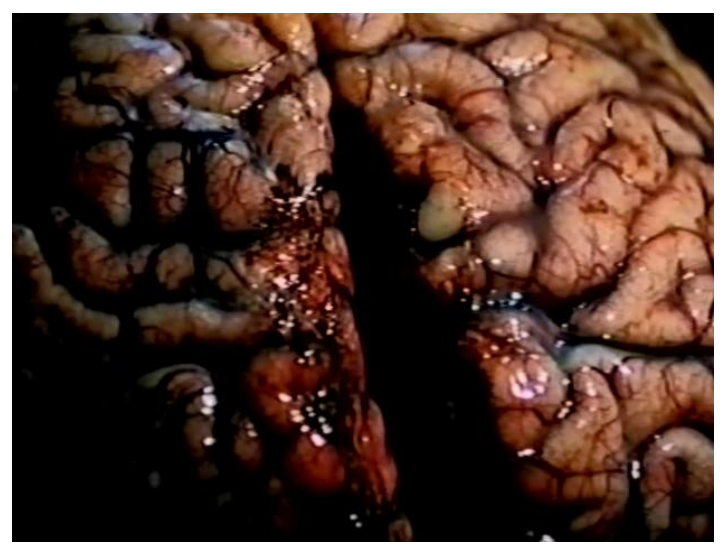

Fonte: O som, ou tratado da harmonia (1984).

A segunda audição de sua voz se dá aos 7' e 30" de filme, após uma personagem expressar que está vivenciando limites e rupturas. Segundos antes de ouvirmos Herbert Daniel, há uma música instrumental que é, ao mesmo tempo, melancólica e cinematográfica. Parece sair da trilha sonora de algum filme épico, num momento de enlevo moral de um personagem heroico. Na imagem, obscura, uma pequena estatueta de metal (que evoca o troféu do Oscar) gira sobre um disco Long Play em execução - talvez a origem da música. Herbert começa a falar, num trecho que dura um minuto e meio. Ele conta que foi "[...] um dos escolhidos para ir para a Ribeira, ou seja, para o treinamento de guerrilha numa mata fechada [...]" (O SOM ou tratado da harmonia, 1984), que ele até então desconhecia.

Figura 7 - Sequência das picaretas, acompanhada do depoimento de Herbert Daniel

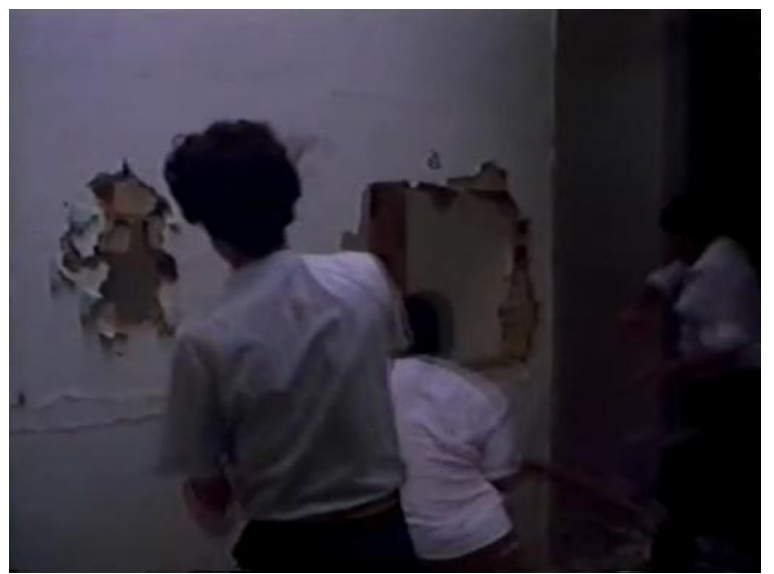

Fonte: O som, ou tratado da harmonia (1984). 
Figura 8 - Sequência das picaretas com fotografia de floresta ao fundo

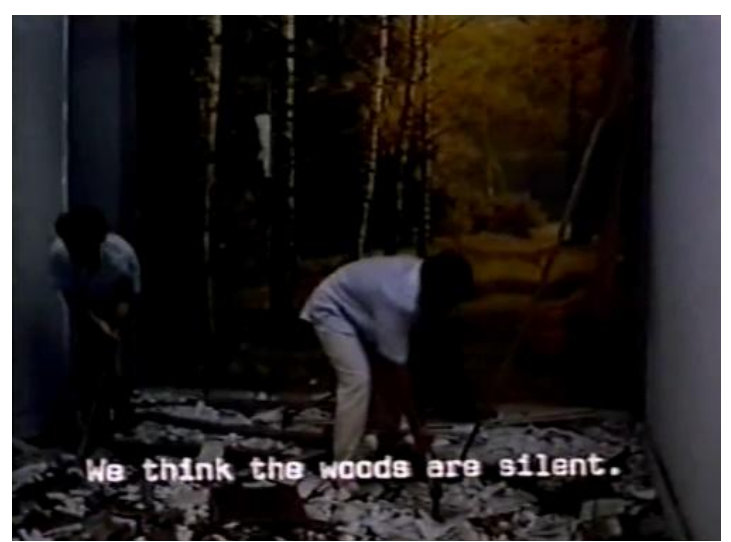

Fonte: O som, ou tratado da harmonia (1984).

Figura 9 - Sequência das picaretas

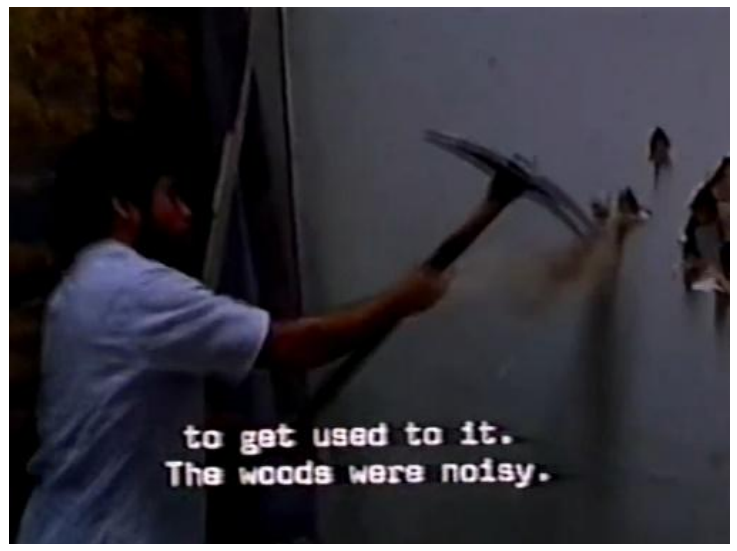

Fonte: O som, ou tratado da harmonia (1984).

A câmera nos leva a um grupo de homens munidos de picaretas que quebram paredes. Uma delas é recoberta por um pôster fotográfico em que se vê uma paisagem serena de floresta (Figura 8). Ouvimos as picaretas e o som dos pedaços de parede que caem, enquanto Herbert Daniel conta sobre sua experiência no Vale da Ribeira13. Fala da falsa impressão que temos de que a mata é silenciosa - impressão contradita pelo ruído agressivo das picaretas e, logo em seguida pela afirmação de que na mata há "[...] uma quantidade de gritos, pios, galhos que se quebram [...]" (O SOM..., 1984, doc. não paginado).

Ele lembra como a mata era constantemente muito barulhenta, e como os momentos de silêncio ali eram profundamente dramáticos, principalmente após um tiro (quando advém um eco, um silêncio, a morte). Mas o que mais marcou a memória de Herbert, nesse

\footnotetext{
${ }^{13}$ Herbert Daniel refere-se à base de treinamentos de guerrilha rural no Vale da Ribeira-SP, criada por Carlos Lamarca em fins dos anos 1960.
} 
sentido, foi o silêncio duro que veio junto com o primeiro ruído de helicóptero que ele lembra de ter ouvido, sobrevoando a mata. 0 eco e o silêncio que se seguiam a esse ruído eram "muito maiores do que o do tiro" (O SOM..., 1984, doc. não paginado). Sua emoção, no caso, intensificava a experiência auditiva, pois os helicópteros faziam parte do enorme aparato montado pelos órgãos de repressão para caçar os guerrilheiros, com evacuação e bombardeio do lugar. Verdadeira chacina ${ }^{14}$. Após essas palavras, a voz de Herbert silencia, enquanto entra o som de helicóptero, uma música latina sentimental, e vemos imagens em plongée sobrevoando uma favela.

A terceira e última audição da voz de Herbert se dá aos 11' e 50" de filme, após rápidas imagens de uma corneta submersa num aquário e dos seus sons distorcidos. Vê-se uma ninhada de ratinhos pelados, movimentando-se agitados, e ouve-se Herbert dizer que "ser homossexual e ser guerrilheiro parecia uma contradição absolutamente insolúvel" (0 SOM..., 1984, doc. não paginado). Ao optar por ser guerrilheiro, explica que fez uso do autoerotismo. A imagem, em agora em contra-plongée, mostra mãos que puxam um fio invisível, enquanto ele fala da masturbação, e da dúvida enorme que lhe surgiu naqueles anos: "Se a revolução era um ato de amor, como então esse enorme ato de amor podia recusar outros atos de amor?" (O SOM..., 1984, doc. não paginado). Esse trecho de 50 segundos evoca uma vídeo-performance.

Além dos depoimentos de Herbert Daniel e da montagem fragmentária e complexa como formas de evidenciar a violência, vale realçar, ainda, as constantes referências políticas ao Brasil. 0 ponto culminante dessa articulação se dá numa sequência quase ao final do filme, enquanto se ouve os primeiros acordes do Hino Nacional que desafina, mesclado à voz emocionada do deputado Auro Moura de Andrade, registrada em 1964. A imagem mostra um gravador de rolo Nigra em close. Sobre ele desliza uma cobra, muito vagarosamente, o que dá a impressão de que o réptil interfere na velocidade do aparelho e no som do hino, por isso desafina. A fita do gravador vai saindo da bobina, e se justapõe à música a voz do então presidente da Câmara de Deputados na última sessão do parlamento em 1964 antes do golpe militar, bradando: "Atenção, senhores deputados! Atenção, senhores deputados! está suspensa a sessão!" Ao fundo, gritos: "Fascista! Comunista!". (O

\footnotetext{
14 Sobre essa "caçada" ocorrida em 1970, Rollemberg (2008) destaca a desproporção das forças em combate: “Para capturar o 'bando terrorista' de meia dúzia de homens, ali estavam o Centro de Operações de Defesa Interna (CODI), a Polícia Militar da Bahia, o Centro de Informações do Exército, o Centro de Informações e Segurança da Aeronáutica, o Centro de Informações da Marinha, IV Exército, Destacamento de Operações de Informações/Centro de Operações de Defesa Interna (DOI-CODI), a Primeira Esquadrilha Aeroterrestre de Salvamento (Parasar), a Operação Bandeirante, a Delegacia de Ordem Política e Social de São Paulo/SP, a Força Aérea Brasileira e a Secretaria de Segurança Pública de São Paulo [...]” (ROLLEMBERG, 2008, p. 115-116).
} 
SOM..., 1984, doc. não paginado). Funciona como uma videoinstalação: a câmera fixa, o movimento do rolo e a interferência do movimento e do peso da cobra sobre o rolo, a instabilidade do som. Segundo Guiomar Ramos (1995), o hino desafinado nesta cena representa a "deterioração da nacionalidade, sua perda" (RAMOS, 1995, p. 72). 0 conjunto surreal de elementos sugere uma identidade nacional caótica naquela primeira metade da década de 80, em que se ensaiavam os primeiros passos da abertura política no país.

Figura 10 - Cobra, gravador de rolo e Hino Nacional

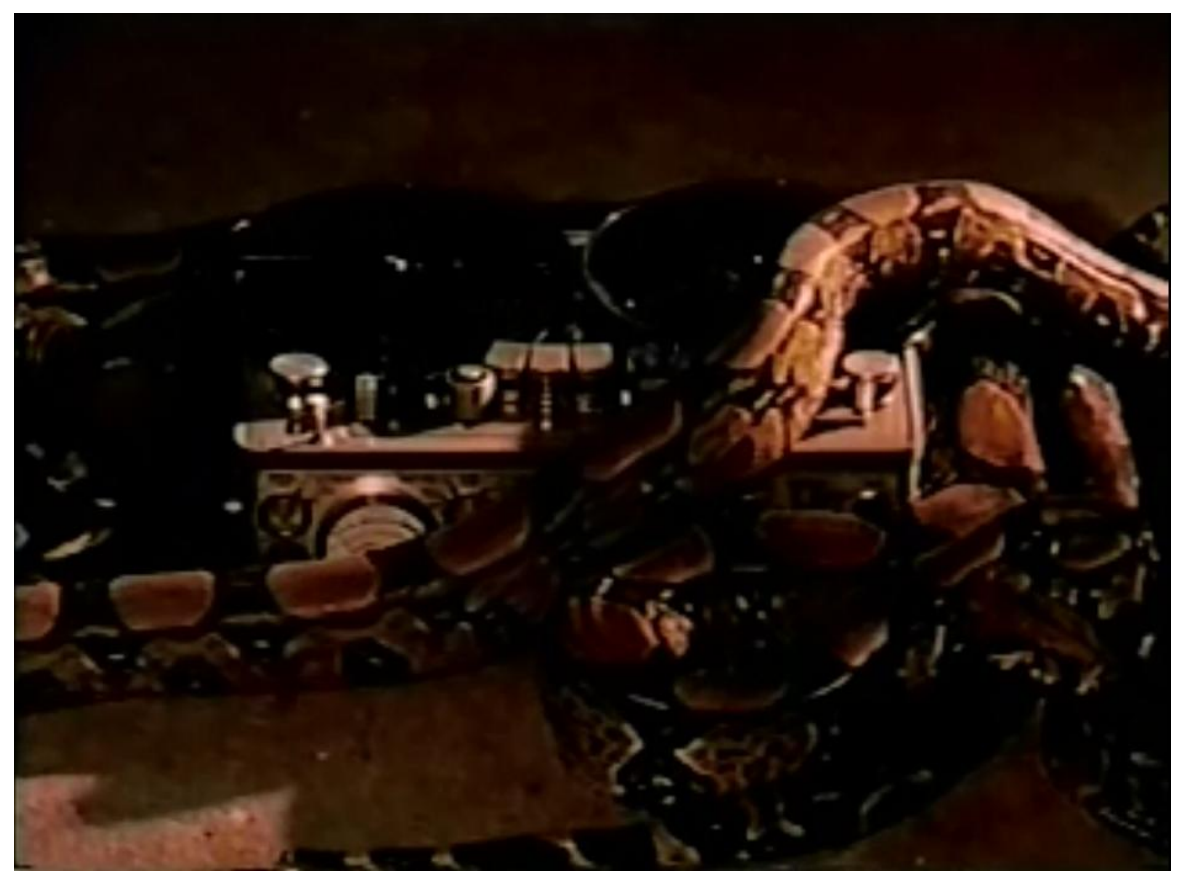

Fonte: O som, ou tratado da harmonia (1984).

A distorção e junção desses sons documentais indica uma crise de identidade que encontra um equivalente naquela crise narrada pelo próprio Herbert Daniel em termos de experiência pessoal, quando precisou escolher entre a revolução política ou a revolução sexual. A grande diferença, pode-se dizer, é que na penumbra na cena do Hino Nacional desafinando, que praticamente encerra o filme, a crise é indicativa não de um sujeito, mas de um tempo na história brasileira, um tempo de se perguntar quem somos nós, afinal?

A ausência de resposta, ou falta de otimismo quanto a uma possível resposta, fica insinuada pelo tenebrismo de boa parte das cenas fílmicas. Arthur Omar, enquanto artista, não isenta o lugar de enunciação desse questionamento. É por meio dos filmes inventivos, herméticos, do seu diálogo com outras formas artísticas, da exposição de seus limites e a 
suas funções no mundo, que ele edifica essa pergunta: quem somos nós, brasileiros, afinal?

\subsection{Um detetive afastado e muitas vítimas da violência}

No filme $O$ Inspetor (1987), ao colocar em cena um detetive de política supostamente bem-intencionado, mas que em 1977 havia sido afastado do seu cargo por solucionar um caso de homicídio que envolvia a elite carioca, Arthur Omar ironiza a função e a honestidade da polícia, enquanto instituição, e coloca em xeque a identidade pessoal de Jamil Warwar. Quem é ele, mestre dos disfarces, ator de fotonovela, um personagem quase cômico no cenário trágico da sociedade brasileira e da polícia corrupta? 0 deboche, nesse filme, é uma forma de denúncia. Mas a presença intensa de armas, batidas de polícia na favela, depoimentos sobre crimes violentos, e a fala de um suposto juiz a favor da pena de morte, apresentadas de modo fragmentário e caótico, não são deboche. São espelhos para nós, espectadores. Aquele close num revólver com inscrição do Exército Brasileiro, no final do filme, questiona: o Exército é a nossa segurança, ou o nosso temor? As forças militares e policiais estão a serviço de quem?

Figura 11 - Cores da bandeira do Brasil e desvelamento de esconderijos de drogas

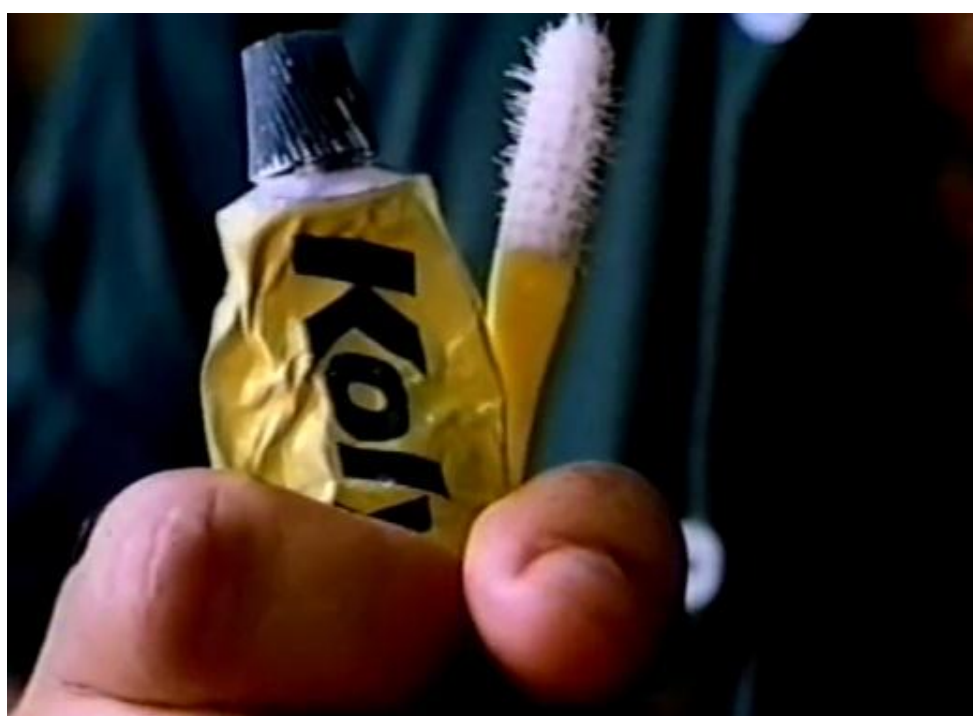

Fonte: O inspetor (1987). 
Figura 12 - Esconderijo de drogas

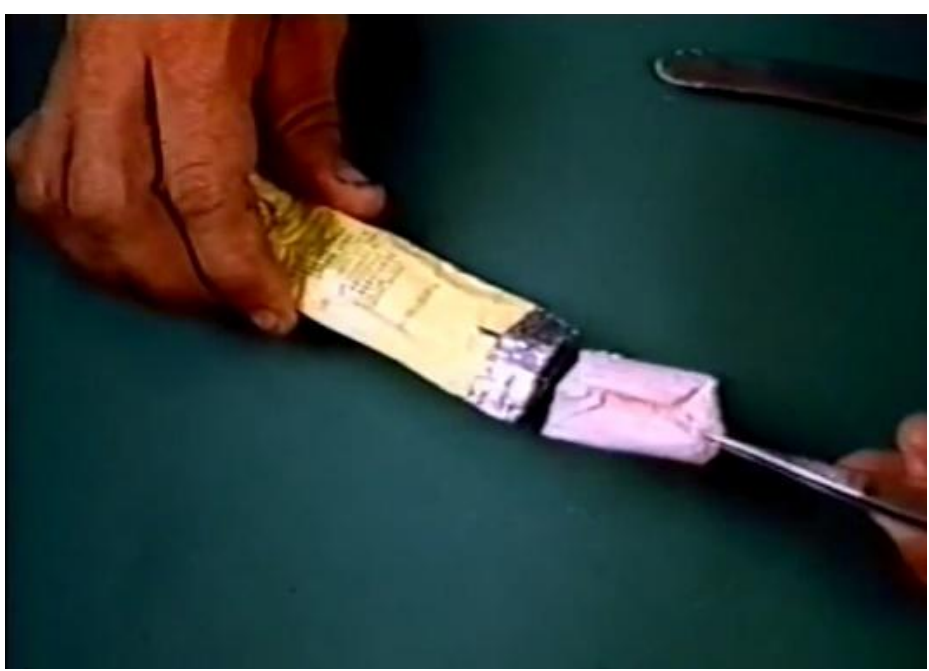

Fonte: O inspetor (1987).

Assim como no filme $O$ Som ou tratado da harmonia (1984), há remissões à ideia de Brasil na chave do pessimismo e da crise identitária que se espraiavam ao longo dos anos 1980. São meras insinuações, mas ganham força à luz do contexto. Um elemento irônico em relação imagem nacional distópica é a voz radiofônica que entoa um Brasil-il-il no momento em que são encontradas papeletas de drogas no interior de um radinho de pilha. Trata-se do único momento do filme em que aparece o nome do país, festejado pelo locutor como se houvesse sido marcado um gol, e isso é simultâneo ao desvelamento do tráfico. Essa ambiguidade poderia ser uma, ao menos, dentre muitas facetas possíveis daquele Brasil ressentido e desarticulado em que viviam Jamil Warwar e Arthur Omar em fins dos anos 80.

Segundos antes, as cores da bandeira nacional surgiram nas imagens de uma bisnaga de creme dental Kollynos em close sobre um fundo verde (Figuras 11 e 12). Dela foram retirados pacotinhos de cocaína (droga que ganhava espaço nos hábitos de consumo da elite milionária). A posição diagonal do tubo, somada à composição cromática da cena remetem claramente à bandeira do Brasil. Por mais que o consumo de cocaína fosse elitizado, ela aparecia como vilã no discurso de combate necessário ao tráfico de drogas no país e, na mídia era associado às favelas. No entanto, os lugares sociais não eram tão bem delimitados no que diz respeito à relação entre policiais, traficantes e grupos de extermínio: "Era comum que policiais desonestos vendessem proteção aos traficantes, matassem os seus concorrentes e até compradores que não pagassem suas dívidas." (COSTA, 1998, p. 29-30). Portanto, as imagens das armas de fogo de origens imiscuídas expressam essas sobreposições dos lugares de bandidos e mocinhos. 
Figura 13 - Jamil Warwar se apresentando

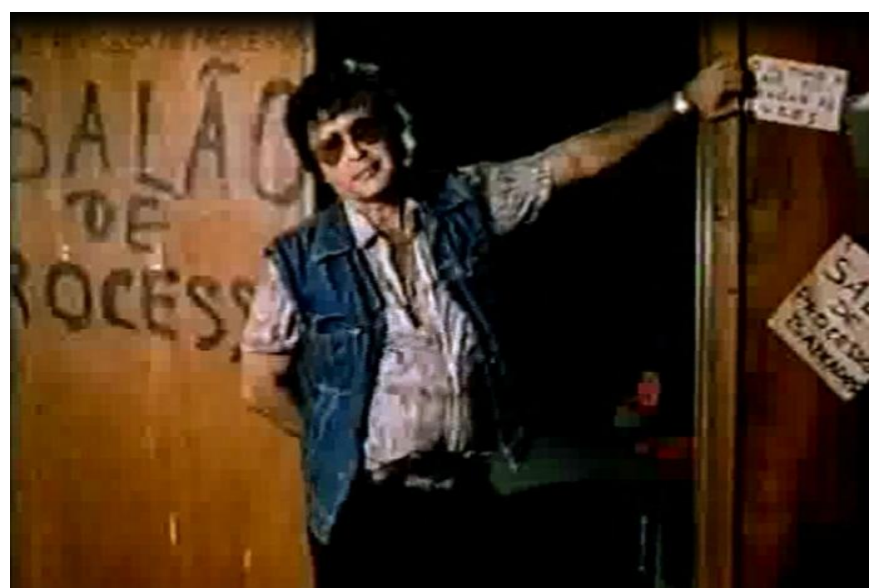

Fonte: O Inspetor (1987).

Figura 14 - Jamil Warwar lendo trecho sobre os esquadrões da morte no seu livro Répto à morte

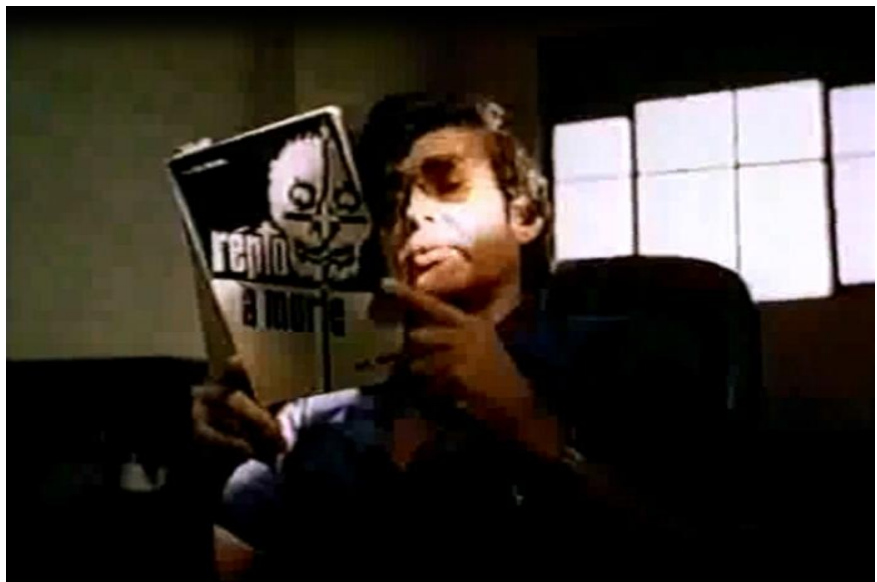

Fonte: O Inspetor (1987).

Nesse sentido, uma cena que fará a ponte entre o curta $O$ Inspetor (1987) e o Ressurreição (1988) é aquela em que Warwar aparece lendo um trecho de livro de sua autoria, o Répto à morte, no qual menciona os esquadrões da morte15. 0 detetive lê dramaticamente enquanto a câmera se aproxima dele. Ao fundo, uma música melodramática evoca algum filme épico em momento de grande heroísmo - assim como acontecera durante o depoimento de Herbert Daniel, em O Som ou tratado da harmonia (1984) -, carregando a cena de uma tonalidade kitsch, reforçada pelas frases lidas em rima:

\footnotetext{
15 "Com origem policial, o Esquadrão da Morte surgiu fundado em um discurso moralista de defesa da sociedade contra os elementos indesejáveis e de manutenção da ordem pública. Mas, desde o seu início, ele esteve ligado com corrupção, venda de proteção para traficantes de drogas, associação com grupos de criminosos." (COSTA, 1998, p. 1).
} 
Mais um bandido que surge deitado com diversos tiros no matagal.

Um crânio sobre dois ossos desenhado num papelão está em cima do marginal.

Esquadrão da morte age: horrorizado exclama em grande manchete o jornal.

O bandido que sucumbiu, coitado, só tinha dez crimes, mas não era mau.

E a opinião pública então é iludida, pois policial arrisca sempre a vida e para não

morrer tem que ter sorte.

Não há policiais que matam sem piedade, o que há são policiais, eis a verdade, que $o$

esquadrão desafia à morte. (O SOM..., 1984, doc. não paginado)

Figura 15 - Fotografias de vítimas de tortura e morte

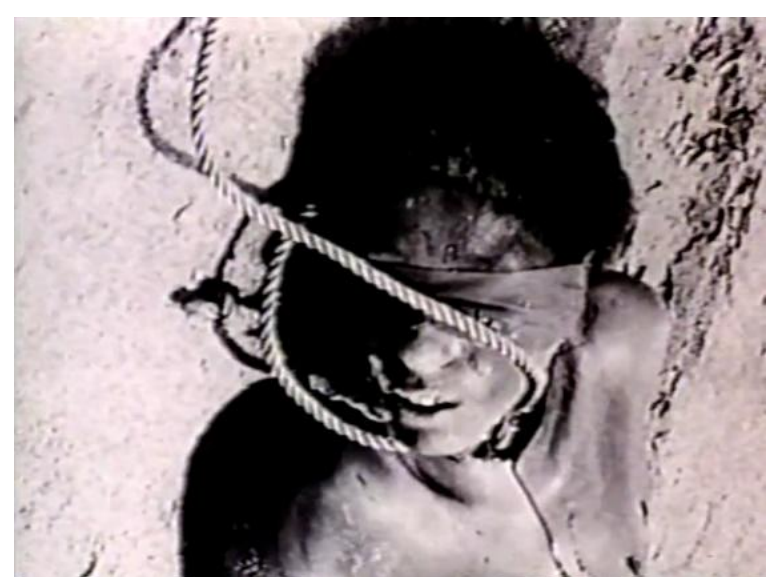

Fonte: Ressurreição (1988).

Figura 16 - Mãos amarradas

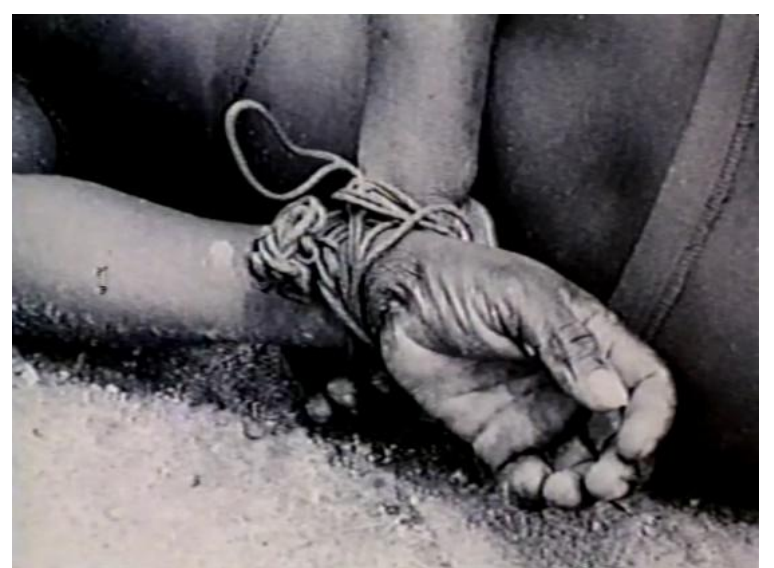

Fonte: Ressurreição (1988).

Passa-se, assim, do universo dos perpetradores para o das vítimas da violência, que ganham a cena em Ressurreição (1988). Neste fotofilme, o mórbido é exacerbado. A ênfase 
passa para o resultado das matanças nas periferias cariocas. 0 curta é pesado, com a montagem herética de fotografias de cadáveres, sinais de tortura (mãos amarradas, corpos amarrados) com músicas religiosas e aplausos. Os seis minutos alongam-se, pois, como dizia Susan Sontag (2003), em alguns momentos é preferível "virar o rosto" do que ver.

Como reagir diante dessas imagens? É aceitável sentir prazer diante de um horror real? Se, a princípio, esse prazer parece inapropriado, nos acostumamos com elas. Sontag (2003) diz que "[...] uma constante dieta de imagens de violência [...]" (SONTAG, 2003, p. 84) difundidas pela televisão e outros meios de comunicação tornou as pessoas indiferentes. Há o risco de a brutalidade física tornar-se antes um entretenimento do que um choque. A curva ascendente da violência e do sadismo aceitáveis na cultura de massa, seja na forma de filmes, seriados, quadrinhos ou jogos digitais, promove “[...] uma imagística que teria feito o público encolher-se e virar a cara de nojo quarenta anos atrás [e que] é vista sem sequer um piscar de olhos por qualquer adolescente nos cinemas" (SONTAG, 2003, p. 84).

Essa banalidade da violência no universo midiático impacta, sem dúvida, na forma como recebemos as imagens que recordam graves crimes e crueldades históricas. Aí, observa-se uma contradição entre ética e estética, no que diz respeito à aceitação de imagens de atrocidades. Ao se tratar de imagens que "documentam" historicamente a violência (e não ficcionalizam), “[...] as pessoas querem o peso do testemunho sem a nódoa do talento artístico [...]", reflete Susan Sontag (2003, p. 26), pois este seria "equivalente à insinceridade ou à mera trapaça" (SONTAG, 2003, p. 26). No senso comum, as fotografias menos elaboradas costumam ser recebidas, diz a autora, "[...] como portadoras de algum tipo especial de autenticidade." (SONTAG, 2003, p. 27).

Tal juízo ético não convence, no fim das contas, se concordamos com a afirmação de Marie-José Mondzain (2009, p. 24) de que as imagens não são violentas em si. Elas não machucam e não matam. É nos usos que se faz das imagens que reside a potência de violência (na manipulação, no direcionamento de informações, sendo que até imagens belas podem ser usadas para produzir violência). Por isso, diz Mondzain (2009), é no relacionamento com as imagens que precisamos aprimorar nosso senso crítico, dissociarnos delas, distanciar-nos e dirigir o nosso olhar para elas enquanto "coisas". 
Figura 8 - Fotografia de vítima de execução violenta no Rio de Janeiro

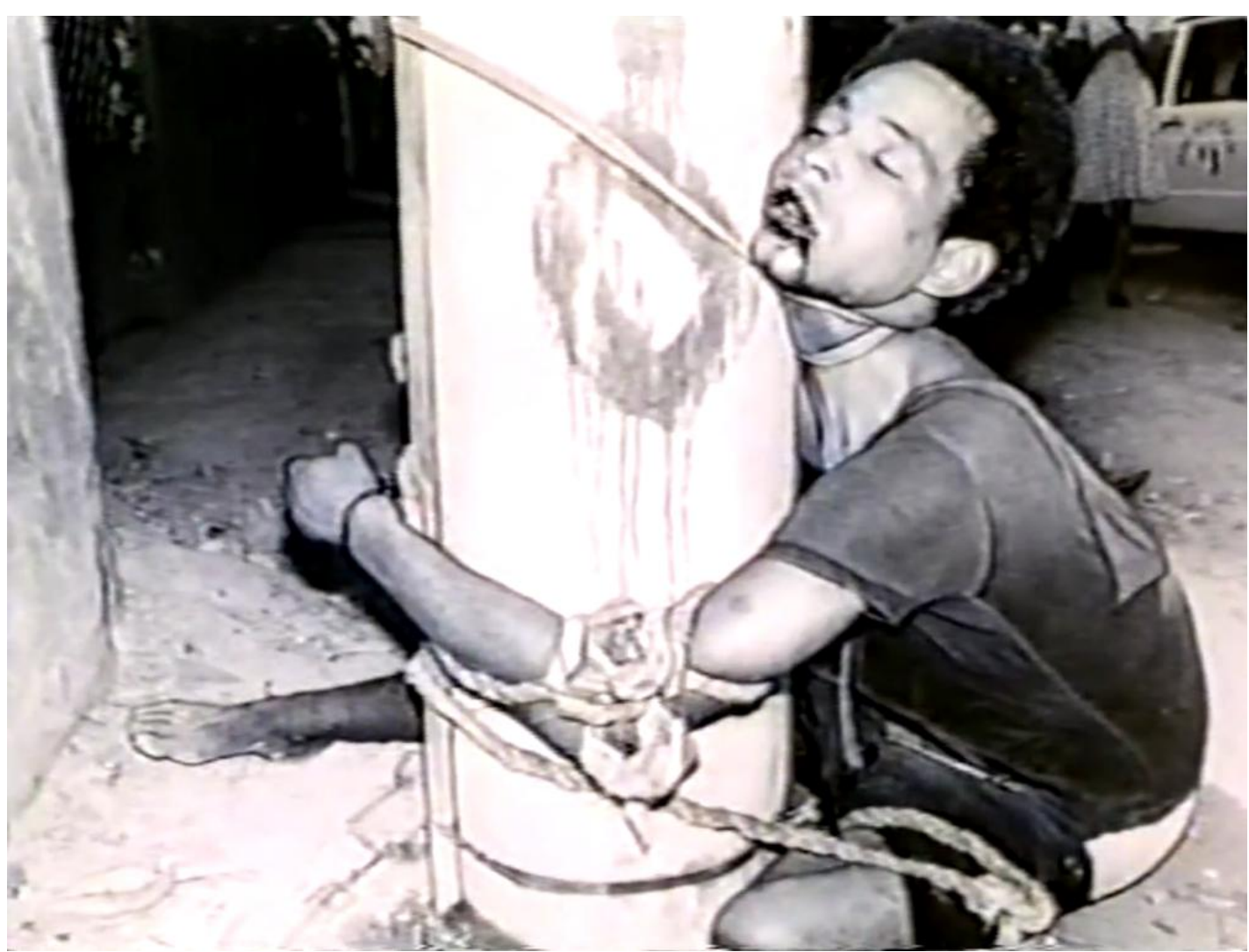

Fonte: Ressurreição (1988).

Deveríamos, enfim, ser capazes de refletir sobre o que significa olhar para tais imagens, sobre a capacidade de assimilar efetivamente aquilo que elas mostram. Mas nem todas as nossas reações "estão sob a supervisão da razão e da consciência" (SONTAG, 2003, p. 80), e maioria das imagens de corpos torturados e mutilados suscita inclusive um interesse lascivo. Na teoria da violência proposta por Omar em seus filmes, essa lascívia é uma provocação.

Em Ressurreição (1988), a junção de horror e delírio (no sentido de um gozo social da sociedade brasileira, já denunciado por Hélio Oiticica nos anos 60 quando lamentava a morte violenta de seu amigo Cara de Cavalo, assassinado pela polícia num ato de vingança) ${ }^{16}$ evidencia a pornografia da morte violenta. Podemos não querer ver, e essa é a escolha passiva. Arthur Omar escolhe não apenas ver, mas mostrar e jogar violentamente na face do espectador o seu lugar hipócrita, ao crer que não faz parte disso tudo, ao se esconder atrás de ladainhas religiosas como o canto entoado por Carmem Costa e Agnaldo Timóteo, que

\footnotetext{
16 Sua denúncia aparece em forma de obra de arte, no B33 Bólide-caixa nº18 - Homenagem a Cara de Cavalo, e também na comunicação $O$ herói anti-herói e o anti-herói anônimo feita por ocasião do evento $O$ Artista Brasileiro e a Iconografia de Massa, ocorrido na ESDI em 1968. Ver: Oiticica (2011, p. 14).
} 
diz: "Queremos Deus, na Pátria Amada, amar-nos todos como irmãos; pela igreja respeitada, são nossos votos de cristão [...]" (RESSURREIÇÃO, 1988). No entanto, esses mesmos que se deleitam com a religiosidade, seus ritos e canções, preferem não encarar de frente a marginalidade, os excluídos e indesejados, que não devem pertencer à "Pátria Amada". Ou, ao contrário, encaram-na com prazer mórbido e justiceiro, pois recorrentemente apoiam a violência contra os ditos marginais. Os aplausos aos músicos populares, venerados pelo público classe média cristão do Brasil são, ao mesmo tempo, aplausos da sociedade civil para essas mortes e para a violência praticada, em grande parte, pela polícia, pelos grupos de extermínio e pelo Estado sobre aquela parcela marginal que não merece o tratamento como irmãos. A arma com selo do Exército ao final de $O$ Inspetor (1987) expressa essa crua realidade. Os cadáveres de Ressurreição (1988) mostram o saldo.

Retomo à pergunta evocada (em mim, como cidadã, e que considero muito significativa nos dias atuais) pelo conjunto dos três filmes: Quem somos nós, brasileiros, afinal?

Arthur Omar não responde a essa pergunta. 0 que ele faz, com uma poética violenta e escancarando a brutalidade estrutural em nossa sociedade, é dar uma forma ao seu pensamento e potencializar a dimensão política do próprio fazer.

\section{Referências}

ADORNO, Sérgio. Exclusão sócio-econômica e violência urbana. Sociologias, Porto Alegre, v. 4, n. 8., p. 84-135, jul./dez. 2002.

AUMONT, Jacques. À quoi pensent les filmes. Paris: Séguier, 1996.

BENJAMIN, Walter. 0 autor como produtor. In: BENJAMIN, Walter. Magia e técnica, arte e política. São Paulo: Brasiliense, 1994.

BENTES, Ivana. Arthur Omar: a imagem sensorial ou um artista híbrido. Toulouse: Presses Universitaires du Mirail, 2001.

BERNARDET, Jean-Claude. Cineastas e imagens do povo. São Paulo: Brasiliense, 1985.

BERNARDET, Jean-Claude. Cinema Brasileiro: propostas para uma história. São Paulo: Companhia das Letras, 2009.

CANONGIA, Ligia. Quase cinema: cinema de artista no Brasil, 1970/80. Rio de Janeiro: Funarte, 1981. 
CAMPOS, Augusto de; PIGNATARI, Décio; CAMPOS, Haroldo de. Teoria da poesia concreta: textos críticos e manifestos 1950-1960. São Paulo: Brasiliense, 1987.

CAMPOS, Augusto de; PIGNATARI, Décio; CAMPOS, Haroldo de. Plano Piloto para Poesia Concreta. Noigrandes, São Paulo, n.4, s/p, 1958.

CHAUÍ, Marilena. A não violência do brasileiro: um mito interessantíssimo. Almanaque, São Paulo, n. 11, p. 01-04, 1980.

COSTA, Marcia Regina. São Paulo e Rio de Janeiro: a Constituição do Esquadrão da Morte. In: ENCONTRO ANUAL DA ASSOCIAÇÃO NACIONAL DE PÓS-GRADUAÇÃO E PESQUISA EM CIÊNCIAS SOCIAIS, 22., 1998, Caxambu. Anais [...]. Caxambu: ANPOCS, 1998.

DUBOIS, Philippe. 0 "estado vídeo": uma forma que pensa. In: DUBOIS, Philippe. Cinema, vídeo, Godard. São Paulo: Cosac Naify, 2004.

GODARD, Jean-Luc. Cahiers du Cinéma, Paris, n. 138, 112 p., dez. 1962. Edição especial Nouvelle Vague.

FRICKE, Chistiane. Novos media: formas não-tradicionais de expressão artística. In: WALTHER, Ingo F. (org.). Arte do século XX. Lisboa: Taschen, 2005. v. 2.

GREEN, James N. 2018. Revolucionário e gay: a vida extraordinária de Herbert Daniel pioneiro na luta pela democracia, diversidade e inclusão. Rio de Janeiro: Civilização Brasileira, 2018.

KAMINSKI, Rosane. As mil faces do inspetor. In: KAMINSKI, Rosane; FREITAS, A.; GRUNER, C.; HONESKO, V.; REIS, P. Imagem, narrativa e subversão. São Paulo: Intermeios, 2016a.

KAMINSKI, Rosane. Um ensaio visual sobre som e identidade: 0 Som ou tratado da harmonia (Arthur Omar, 1984). In: BERARDO, Rosa (org.). Cultura, identidade cultural e representação da alteridade. Goiânia: Gráfica da UFG, 2016b. Ebook (Coleção Desenredos, v. 9).

KAMINSKI, Rosane. 0 curta-metragem brasileiro e as figurações da violência (19861994). [S.l.]: ECA-USP, 2017. Relatório de Pós-doutorado em Meios e Processos Audiovisuais.

KAMINSKI, Rosane. Emoção e violência em Ressurreição (Arthur Omar, 1988). In: MORETTIN, E.; NAPOLITANO, M. (org.). 0 cinema e as ditaduras militares: contextos, memórias e representações audiovisuais. São Paulo: Intermeios, 2018.

MACHADO, Arlindo. Apresentação. In: DUBOIS, Philippe. Cinema, vídeo, Godard. São Paulo: Cosac Naify, 2004.

MACHADO, Arlindo. O filme ensaio. In: CONGRESSO BRASILEIRO DE CIÊNCIAS DA COMUNICAÇÃO, 26., 2003, Belo Horizonte. Anais [...]. Belo Horizonte: INTERCOM, 2003.

MONDZAIN, Marie-José. A imagem pode matar? Lisboa: Nova Vega, 2009. 
O INSPETOR. Direção: Arthur Omar. Produção: Arthur Omar. Brasil: Melopeia, 1987. Película 35mm (11 min) son., color.

O SOM ou tratado da harmonia. Direção: Arthur Omar. Produção: Arthur Omar. Brasil: Melopéia Cinematográfica, 1984. Película 35mm (15 min) son., color..

OITICICA, Hélio. 0 herói anti-herói e o anti-herói anônimo. [S.l.]: Sopro 45, fev. 2011. Panfleto político-cultural.

OMAR, Arthur. Entrevista cedida a Guiomar Ramos em 1994. Arquivo digital cedido pelo cineasta.

PINHEIRO, Paulo Sérgio. Violência do Estado e classes populares. Revista de Ciências Sociais, Rio de Janeiro, v. 22, n. 3, p. 05-24, 1979.

RAMOS, Maria Guiomar. Espaço fílmico sonoro em Arthur Omar. 1995. Dissertação (Mestrado em Artes) - Escola de Comunicações e Artes, Universidade de São Paulo, São Paulo, 1995.

SCHWARZ, Roberto. Cultura e política. São Paulo: Paz e Terra, 2001.

SONTAG, Susan. Diante da dor dos outros. Rio de Janeiro: Companhia das Letras, 2003.

RANCIÈRE, Jacques. A partilha do sensível: estética e política. São Paulo: Editora 34, 2005.

RESSURREIÇÃO. Direção: Arthur Omar. Produção: Arthur Omar. Brasil: Melopeia/Cortéx, 1988. Película 35mm (6 min) , son., p \& b.

ROLLEMBERG, Denise. Carlos Marighela e Carlos Lamarca: memórias de dois revolucionários. Acervo, Rio de Janeiro, v. 21, n. 2, p. 105-122, jul./dez. 2008.

VELHO, Gilberto. Mudança, crise e violência. Rio de Janeiro: Civilização Brasileira, 2002.

VIEIRA, João Luiz. A reflexividade na tela. 4⿳亠丷a Mostra Curta Cinema. Catálogo. Rio de Janeiro, 1994.

XAVIER, Ismail. 0 avesso do Brasil. Folha de São Paulo, São Paulo, 19 jan. 1997. Caderno Mais!.

XAVIER, Ismail. Alegorias do subdesenvolvimento. São Paulo: Cosac Naify, 2012.

ZALUAR, Alba. Um debate disperso: violência e crime no Brasil da redemocratização. São Paulo em Perspectiva, São Paulo, v. 13, n. 3, p. 1-143, 1999. 


\title{
The Arthur Omar films as "ways of thinking" the violence of Brazil in 1980s
}

\begin{abstract}
Arthur Omar is a filmmaker and a visual artist who has been working from the 1970s to today. Throughout the 1970s and 1980s, Omar made experimental films that can be discussed in regard to their poetic violence. In his films, the filmmaker emphasized multiple features of reality, and articulated them in a complex, not obvious way. Throughout the 1980s, Omar made, among others, the films $O$ Som ou tratado da harmonia (1984), O Inspetor (1987) and Ressurreição (1988), which will be analyzed in this paper. In these films, the poetic violence of his early works will be regarded, as well as the violence as a social phenomenon. This paper intends to discuss these three films as if they proposed a "theory of violence" and situate them before the aesthetic and political debates of their context of production.
\end{abstract}

\section{Keywords}

Arthur Omar. Brazilian cinema. Violence. Filmmakers' theory.

Recebido em 12/05/2019

Aceito em 26/06/2019 